\title{
Improving the Management of Parthenium hysterophorus to Enhance Okra Production through the Application of Chemicals, Adjuvants and Plant Extract Blends in Pakistan
}

\author{
Muhammad Adnan ${ }^{1 *}$, Muhammad Sikander Hayyat ${ }^{1}$, Qaisar Mumtaz ${ }^{1}$, Muhammad Ehsan Safdar', \\ Fazal ur Rehman ${ }^{2}$, Haroon Ilahi ${ }^{3}$ and Koko Tampubolon ${ }^{4}$

\begin{abstract}
${ }^{1}$ Department of Agronomy, College of Agriculture, University of Sargodha, Pakistan; ${ }^{2}$ Department of (Soil Sciences), The University of Swabi, Pakistan; ${ }^{4}$ Program Study of Agrotechnology, Faculty of Agriculture and Animal Husbandry, Universitas Tjut Nyak Dhien, Indonesia
\end{abstract} \\ Plant Pathology, College of Agriculture, University of Sargodha, Pakistan; ${ }^{3}$ Department of Agriculture
}

*Corresponding author: mughal3368@gmail.com

\begin{abstract}
Vegetables are consequently experiencing great yield losses due to weed infestation. Weed management is extremely important for sustainable crop production in all cropping systems. This review paper aimed to provide general information and alternative recommendations for the management of Parthenium hysterophorus weed by chemicals, adjuvants and plant extracts in okra. Different strategies have been used to control parthenium, but no single management solution is sufficient to handle parthenium; hence, different management options need to be combined. Only an integrated approach will achieve effective control over this weed. In areas where parthenium natural enemies are absent, chemical control is an important method of managing this weed. In the control of this plant, the use of chemical herbicides such as chlorimuron ethyl, glyphosate, atrazine, ametryn, bromoxynil and metsulfuron are considered to be efficient. Moreover, various plants have allelopathic potential and attempts have been made to use them in parthenium control. Three allelopathic grasses, namely, Achyranthes aspera, Syzygium cumini and Acacia nilotica are able to minimize the plant growth and inhibit early seedling growth of exotic weed $P$. hysterophorus. The results recommend that the control of parthenium in okra and other summer vegetables using chemical herbicides with single and combination mode of action is still effective compared to the use of plant extracts. The use of herbicides by adding adjuvants has the potential to minimize the use of excessive herbicides.
\end{abstract}

Keywords: adjuvant; chemicals control; integrated weed management; plant extract; ragweed parthenium

Cite this as: Adnan, M., Hayyat, M. S., Mumtaz, Q., Safdar, M. E., ur Rehman, F., Ilahi, H., \& Tampubolon, K. (2021). Improving the Management of Parthenium hysterophorus to Enhance Okra Production through the Application of Chemicals, Adjuvants and Plant Extract Blends in Pakistan. Caraka Tani: Journal of Sustainable Agriculture, 36(1), 165-174. doi: http://dx.doi.org/10.20961/carakatani.v36i1.48215

\section{INTRODUCTION}

The economy of Pakistan is dependent on agricultural sector. Only agriculture sector contributes about $18.5 \%$ to the GDP and about $38.5 \%$ to the labour employment (Government of Pakistan, 2019). The production of vegetables are very significant for the nutrition fulfillment and have many medical benefits because of their dietary fiber, vitamins and minerals (Yahia et al., 2019). Okra belongs to Malvaceae family and its immature fruits and leaves are commonly consumed as vegetable. It is mainly grown in home gardening in combination with cereal crops. In Pakistan, actual okra production is less compared to its potential due to many

\footnotetext{
* Received for publication January 31, 2021

Accepted after corrections February 17, 2021
} 
reasons such as conventional method of sowing, imbalanced application of fertilizers, high cost of input and poor management of weeds. The pod yield losses by weed infestation in okra ranged from 69-74\% (Zareen et al., 2017; Santos et al., 2020). Weeds cause serious concerns for the stability of ecosystem and socio-economic development of marginal and small farms, specifically particularly in semi-arid regions and this threaten smallholder production (Pratt et al., 2017; Shekhawat et al., 2017).

The management of terrestrial weed is of a great concern for the scientific community (Saha et al., 2018). Parthenium (Parthenium hysterophorus L.) is a broadleaf weed belonging to family Asteraceae. It is native to tropical and sub-tropical Americas and was undeliberately brought into numerous countries. Parthenium is thought to have brought into Indo-Pak sub-landmass in 1955 through the import of nourishment grains (Marwat et al., 2010) yet its accurate wellspring of presentation into Pakistan has not yet been found. It is suspected to have come through domesticated animals, nourishment products debased with the weed, seed or vehicles transport from India. Weeds are the main factors, responsible for the low production of crops (Hussain et al., 2020). Hence, weed management is very important in sustainable agriculture for integrated weed management based on production that is environmental friendly and economical (Matloob et al., 2019; Aziz et al., 2021).

Parthenium leads to significant yield reduction in wheat (Mayo and Abbas, 2020). Significant reductions in maize have also been reported by the presence of parthenium (Rehman et al., 2020). Main phenolics which are present in parthenium are vanillic, caffeic, chlorogenic, ferulic and anisic acids (Singh et al., 2004). The life cycle of parthenium is almost 4 to 8 months under suitable soil moisture status (Belgeri et al., 2020). It can attain height up to $30-150 \mathrm{~cm}$ and has a capacity to produce seeds up to 26,000 per plant. The most appropriate temperature for parthenium weed growth was $22-25^{\circ} \mathrm{C}$ (Gnanavel, 2013). As heavy use of herbicide causes phytotoxic effects on crop and results in environmental hazards, scientists are searching for strategies to minimize their use (Mehdizadeh et al., 2020). Moreover, currently, parthenium have been controlled by employing synthetic herbicides which are proven to be very effective while extensive use of these chemicals are causing negative impact on environment by their accumulation in the water and soil in addition to their effects on the biological diversity (Leszczyński et al., 2019). Moreover, these pesticides are persistent in nature and cause health hazard for agro-ecosystem and living beings (Sharma et al., 2019). In addition to this, repeated use of herbicides with the same modes of action caused a strong selection pressure on the target populations of weeds; the consequence is that various cases of the herbicides resistance have been evolved worldwide (Powles and Yu, 2010).

One of the conceivable approaches to reduce the weeds' growing problem is to reduce their doses through enhancing their efficacy by mixing with adjuvants or other reasonable bio-enhancers (Mehdizadeh et al., 2020). The adjuvant enhances the efficiency of herbicide by altering its surface active properties at the leaf surface, improving herbicides selectivity and uniform shower drops inclusion on plant tissue as opposed to molding up and moving off (Tagour et al., 2011). One of the easy and reliable method of minimizing ecological risks and reducing herbicide cost is the use of adjuvants. Adjuvants are the supreme significant ingredients in the construction of natural action of herbicides. These are important for easy herbicide mixing and application (Hess and Foy, 2000). In addition to this, the use of allopathic extracts of plants along with the mixture in herbicide is a way of improving efficacy of existing herbicide thus reduce herbicide dose. Prickly-chaff (Achyranthes aspera L.) belongs to Amaranthaceae family is very much allelopathic in nature. This is enriched with many allelopathic complexes such as alkaloids, ketones, phenolics (caffeic, gallic, m-coumaric, syringic and chromatotropic acid), oleanolic acid and saponins. The A. aspera allelopathic potential against parthenium has been observed because of its higher contents of total phenols (Safdar et al., 2016).

This review was aimed to provide general information and alternative recommendations for the management of parthenium weed by chemicals, adjuvants and plant extracts in okra (Abelmoschus esculentus L.).

\section{MATERIALS AND METHOD}

This paper was made by reviewing some relevant articles to find out the most suitable 
method for parthenium weed control in okra plants. For this purpose we reviewed several journal articles, conference proceedings, books and book chapters on the yield loss caused by parthenium (Parthenium hysterophorus) weed, chemical weed control, use of adjuvants in herbicide formulations and use of plant extracts as natural herbicides to suppress the parthenium growth. After data were collected, we compared all of the information. At the end of the discussion, several alternative recommendations can be used to suppress the growth and spread of parthenium weed in the agricultural field.

\section{RESULTS AND DISCUSSION}

\section{Yield losses due to parthenium}

Vegetables are considered as poor weed competitors which consequently experiencing yield loss by weed infestation. Singh and Singh (1994) noted $91 \%$ of yield decrease in onion because of the uncontrolled weed conditions. Similarly, $80 \%$ decrease in the yield of okra (Abelmoschus esculentus L.) (Singh et al., 1993) and $49 \%$ in cauliflower (Brassica oleracea L.) (Porwal and Singh, 1993) occurred because of severe weed occurrence. Parthenium weed is well known to be serious crop yield reducer. This weed has been accounted to cause huge vintage reduction in Moench (40-95\%), Lycopersicon esculentum Mill. (63\%), maize (21-53\%) and Helianthus annuus L. (Safdar et al., 2015; Safdar et al., 2016).

Khan et al. (2014) accompanied an experiment to estimate the harvest losses in agricultural crops including oilseed, forage, sugar, vegetable, agroforestry and flowering crops due to infestation of parthenium weed. Results suggested maximum yield losses due to parthenium in Saccharum officinarum (64.15\%) followed by Eruca sativa (63.3\%), Helianthus annuus (57.8\%), Brassica campestris (57.6\%), Trifolium alexandrinum (56.9\%) and Populus sp. (54.6\%). Vegetable and fodder crops i.e. potato (Solanum tuberosum), lady's finger and garlic (A. sativum) were also severely damaged by parthenium. Maximum yield losses were recorded in $E$. sativa $(55 \%)$ and sunflower $(52.5 \%)$ due to infestation of parthenium. In addition to this, it is a serious invasive weed of sorghum (Asif et al., 2020).

\section{Chemical weed control}

Various investigations showed sharp and successful control of parthenium through herbicides. Various photosynthetic substances like amino acid amalgamation and glutamine synthase inhibitors showed effective response to kill parthenium as compared to the herbicides which have other physiological mechanism. Besides, post-emergence herbicides used at early growing stages effectively handle it. There are different methods which are used in agricultural crops to control weeds including physical, biological, cultural, mechanical and chemical methods. Among all these methods the quickest, effective, cheap and reliable method is chemical method for handling the weed. The utmost important advantage of this technique is that it is least pretentious by the drastic ecological situations including wind, temperature humidity and rainfall etc.

Khan et al. (2012) carried out herbicide screening test at non-cropped area by including atrazine, metribuzin, S-metolachlor, pendimethalin, bromoxynil + MCPA, atrazine $+\mathrm{S}$ metolachlor, triasulfuron + terbutryn and glyphosate. Out of all of these herbicides, metribuzin and glyphosate was proved to be most suitable against parthenium. Among six herbicide treatments, the most proficient control of parthenium and other related weeds in maize crop was given by pre-emergent use of S-metolachlor + atrazine (Khan et al., 2014). Rehman et al. (2017) screened the efficacy of various herbicides viz. pendimethalin, S-metolachlor + atrazine, bromoxynil + 2-methyl4-chlorophenoxyacetic acid and atrazine at their prescribed (407, 711, 445 and $469 \mathrm{~g}$ a.i.ha ${ }^{-1}$ ), half lower and half higher dosages against parthenium weed in spring season maize. They concluded that S-metolachlor + atrazine (postemergence) at its suggested rate was the most reasonable herbicide that gave the highest parthenium weed control along with the higher maize grain yield.

\section{Application of adjuvant}

An adjuvant is a compound that is combined with herbicide formulation to make its blending and application less demanding or it enhances the effectiveness of that herbicide (Hess and Foy, 2000). Limited use of herbicides can reduce many environmental problems and increase cropping system sustainability. As it might help in improving herbicide effectiveness, the dose of herbicide required to accomplish a given impact is diminished as much as 5-10 folds while cost 
depends on cultivar and material used (Hazen, 2000). Adjuvant application significantly affect the weed infestation (Akhter et al., 2017). Thus, including an appropriate adjuvant in herbicide formulation or its tank-mixed application can reduce the herbicidal load on crop and furthermore lessens its expense for killing the weeds. Now and again, an adjuvant may upgrade the ability of a certain herbicide portion to kill the targeted weed species without harming different plants including crops, thus improves its selectivity (Hess and Foy, 2000). However, the presence of proper adjuvants and sprayers are lacking in chemical weed control (Nosratti et al., 2017).

For an excellent weed control, the use of herbicides in combination with adjuvant is necessary. Adjuvants also have a potential to enhance herbicides efficacy to destroy the embattled weed which damaging the plant (Hess and Foy, 2000). Use of proper adjuvant has a potential to enhance the herbicide ability to control weeds without damaging the yield of the crop. Important impact of adjuvant has been the recover attributes of herbicide mixture, impact on sublimation, upgrade of maintenance, alteration or improvement of spray pledges and additionally an enhanced entrance and relocation. Alkyl ether sulfate (AES) has been ended up being a decent adjuvant as it can help in reducing herbicide dose up to $75 \%$ of prescribed dose without impairing its adequacy and brought about higher grain yield (Tanveer et al., 2017).

Singh et al. (2004) brought about an investigation to monitor the adequacy of glyphosate only and in mixture with additives (MON 0818) to minimize the density of parthenium. The findings of his study suggest that mixture of herbicide at $2.7 \mathrm{~kg} \mathrm{ha}{ }^{-1}$ with adjuvant enhanced the effectiveness of glyphosate and resulted in efficient and fast control of parthenium when contrasted with complete dosage $\left(5.4 \mathrm{~kg} \mathrm{ha}^{-1}\right)$ of glyphosate. A comprehensive management of parthenium by the practice of glyphosate at $3 \mathrm{~L} \mathrm{ha}^{-1}$ in combination with $150 \mathrm{~g}$ of basis salt and urea at $150 \mathrm{~g}$ at 6 to 8 leaf stage was mentioned by Bekeko (2013). His results showed that urea and basic salt have a potential as an adjuvant and leads to faster mortality of parthenium. However, at lateral stages of parthenium growth, this treatment has less death rate of parthenium.
Javaid et al. (2012) did a pot trial to assess the potential of two adjuvants to find their adequacy in enhancing the action of five herbicides sprayed at suggested dosage at 2-4 leaf periods and at less dosage $(75 \%)$ on Emex spinosa at foliage-leaf and 2-4 leaf stage. Expansion of AES as adjuvant to diminished rate of carfentrazone ethyl and fluroxypyr + MCPA updated their reasonability, with biomass decline and $100 \%$ death of E. spinosa. Bromoxynil + MCPA with adjuvant in like manner realized $100 \%$ control of E. spinosa. AES improved the tribenuron-methyl adequacy at diminished rate at leaf stages. An experiment was conducted to check the efficacy of AES as adjuvant to control E. australis in wheat crop. In this experiment, alkyl ether sulfate was used in combination with carfentrazoneethyl which brought about in almost 94\% control of it. The reason for this effective control is that AES which was used as adjuvant amplified the phytotoxicity of herbicides against the weed. AES in mixture with Bromoxynil + MCPA resulted in maximum yield in wheat. However, the yield of wheat grain where carfentrazoneethyl was applied along with adjuvant AES was lower in contrast to its wheat production when Bromoxynil + MCPA in combination with AES was applied due to the injury of wheat plant by carfentrazone-ethyl along with adjuvant AES (Javaid et al., 2012).

In field tests, Javaid and Tanveer (2013) inferred that with the inclusion of adjuvants (AES, sodium salt and greasy liquor ethoxylate) to carfentrazone-ethyl herbicide, $94 \%$ control of three-cornered jack (Emex australis) was brought about in wheat. Among the herbicides utilized, the greatest increment in phytotoxicity against three-cornered jack was seen in tribenuron-methyl by mixing with either adjuvant. In another field test, pre-emergence foliar spray of four herbicides viz., iodosulfuron-methyl sodium, fluroxypyr + tribenuron-methyl + clopyralid bromoxynil + MCPA and mesosulfuron-methyl + iodosulfuronmethyl sodium, (pre mixed details) at their prescribed, 14.2, 244.5, 10, (444.6 $\mathrm{g}$ a.i. $\left.\mathrm{ha}^{-1}\right)$ and $25 \%$ diminished doses in tank-mixed application of AES Na salt at $400 \mathrm{~mL} \mathrm{ha}^{-1}$ as adjuvant was checked against communal goosefoot (Chenopodium album) and field bindweed (Convolvulus arvensis) in wheat. It was noticed that out of herbicide plans, $75 \%$ dose of bromoxynil + MCPA and iodosulfuron-methyl 
sodium along with AES adjuvant were more effective against weeds along with the higher grain yields of wheat (Tanveer et al., 2017).

\section{Application of plant extracts}

The utilization of allopathic plant extracts in mixture with herbicide is another choice of improving its profile adequacy; thus, useful in reducing herbicide dose. Achyranthes aspera L. locally identified as prickly-chaff flower is highly allelopathic in nature which belongs to family Amaranthaceae. Achyranthes aspera has a height of 1-2 meter and it is a perennial herb. The color of stem is purple with pointed streaked and usually have branches at the base. It usually spreads along roadsides and wasteland areas. It exists throughout summer season as its life cycle ranges from spring to winter. A. aspera is enriched with various allelochemical compounds including, dihydroxy ketones, alkaloids, saponins, phenolics and oleanolic acid (Srivastav et al., 2011)

The extract of $A$. aspera was noted as exceedingly phytotoxic counter to parthenium weed. Its pre- and post-emergence herbicidal potential against parthenium weed has been recorded (Safdar et al., 2016). Cheema et al. (2003) conducted a field investigation to decide the viability of several herbicides at their less dosages (S-metolachlor and pendimethalin) with the reasonable mixture of concentrated sorgaab (sorghum plant separate) for effective weed management of weeds in cotton. They found that $1 / 3$ of the prescribed dose of S-metolachlor at $667 \mathrm{~g}$ a.i. ha $\mathrm{a}^{-1}$ along with concentrated sorgaab at $10 \mathrm{~L} \mathrm{ha}^{-1}$ decreased dry matter of weed by $58-71 \%$ and $1 / 3$ dose of pendimethalin at $333 \mathrm{~g}$ a.i. ha ${ }^{-1}$ along with concentrated sorgaab at $10 \mathrm{~L} \mathrm{ha}^{-1}$ diminished dry matter of weeds by $50-74 \%$.

The most elevated phytotoxic suppressive activity of $A$. scholaris among eleven plant species was demonstrated by Banerjee and Pandey (2015) against germination and seedling growth of parthenium. Mehmood et al. (2011) discovered phytotoxic impact of fluid and n-hexane bark concentrates of Syzygium cumini and Acacia nilotica against germination and seedling development of parthenium. Cheema et al. (2005) conducted a field trial to evaluate the effect of various herbicides at reduced rate to handle weeds in transplanted rice. The herbicides selected for experiment were ethoxysulfuron ethyl and butachlor and sorgaab at $12 \mathrm{~L} \mathrm{ha}^{-1}$. Results showed a significant increase in paddy yield (12.57\%) in plot where sorgaab at $12 \mathrm{~L} \mathrm{ha}^{-1}$ with reduced rate of butachlor at $600 \mathrm{~g}$ a.i. $\mathrm{ha}^{-1}$ was used. Sorgaab at $12 \mathrm{~L} \mathrm{ha}^{-1}$ in combination with less dose of herbicides gave extreme reduction in dry matter of weeds (76.1 to $77 \%$ ). The herbicidal capability of $5 \%, 1 \%, 3 \%, 2 \%$, $4 \%$ and (w/v) leaf water concentrates of four tree/shrub species viz., Ziziphus mauritiana L., Eugenia jambolana Lam., Ziziphus jujuba L., Ricinus communis L., was evaluated to see their effects on propagation and seedling growth of parthenium weed. The outcomes demonstrated that $R$. communis initiated most extreme decreases in germination rate $(79 \%)$ of parthenium while the greatest decreases in its seedling length (47\%) and seedling life list (97\%) were appeared by Z. mauritiana (Safdar et al., 2013).

Safdar et al. (2016) achieved lab and green house experiment to examine herbicidal ability of Datura metel, Achyranthes aspera, Rumex dentatus and Alternantherap hiloxeroides against parthenium weed. In perspective of pre and postemergence inhibitory possessions of their watery concentrates to damage parthenium germination and seedling biomass, they considered that A. aspera is the utmost recommended plant which can be considered as bio-herbicide to manage weeds. They sequestered around six phenolic mixes (gallic corrosive, chromatotropic corrosive, caffeic corrosive syringic corrosive, m-coumaric corrosive, 4-hydroxy-3-methoxy benzoic corrosive) at greater doses from plant isolates occupied from effectively developing plants of A. aspera. Tanveer et al. (2014) exhibited that among plant parts of A. aspera, its root had the highest phytotoxic capacity against germination of pearl guar, maize, sorghum and millet, crops because of occurrence of ferulic acid, vanillic acid and p-coumaric acid at upper concentrations. Achyranthes aspera have good potential of allelopathic plant. An experiment was carried out by Tanveer et al. (2014) to evaluate the effect of A. aspera on the propagation of Cyamopsis tetragonolobus L., Sorghum bicolor L., Zea mays L., Pennisetum americanum L. under the laboratory conditions. Results suggested that all parts of the A. aspera had a significant influence on final germination count, average germination period and length of seedling. 
Root extract of $A$. aspera indicated extreme inhibitory influence on germination of millet and sorghum. They used root extract with 1,2,3, 4 and $5 \%(\mathrm{w} / \mathrm{v})$ and other parts of A. aspera with $5 \%(\mathrm{w} / \mathrm{v})$. Achyranthes aspera also showed allelopathic effect on Oryza sativa L. Results also predicted that $A$. aspera showed more inhibitory action on germination of rice as compared to L. Camara. Alkari and Chaturvedi (2014) arranged a trial to evaluate the phytochemical properties of A. aspera. The results showed that A. aspera was enriched with various types of triterpenoids, steroids, diterpenoid, diterpenoids, cardiac glycosides, polyphenols, saponins and sesquiterpene lactones. Results showed that alcoholic leaf and stem extracts resulted in maximum percentage of reduction (28.98\%) with a time of 8 hours and stem extract of stem $(35.17 \%)$ at 3 hours in volume of paw as compared to the standard value. Another experiment conducted by Gupta and Narayan (2010) also showed that leaf extract of A. aspera had a significant effect on wheat and pea development and germination.

\section{Recommendations for parthenium weed control}

Based on the research until now, adequate data is accessible with respect to yield loss because of parthenium weed in vegetables and different crops. Chemical control of parthenium weed in different crops through various herbicides has been well documented. However little is established about herbicidal control of parthenium weed in vegetables. Liquid extracts from various plant species particularly $A$. aspera have been generally tried for their herbicidal action against parthenium. Despite the fact that herbicidal capability of allelopathic plant extracts in controlling parthenium and use of adjuvants in lessening herbicide dose has been entrenched, yet little exertion has been made to use adjuvants or allelopathic plant concentrates to limit herbicide dosages in controlling parthenium in vegetables. In this manner, there is a need to investigate their tank-mixed applications along with herbicides in vegetables.

\section{CONCLUSIONS}

This review concluded that parthenium weed control in okra through application of chemical herbicides with single and combination mode of action is still effective compared to the application of plant extracts. The use of herbicides by adding adjuvants has the potential to reduce application of excessive herbicides and increasing cropping system sustainability.

\section{ACKNOWLEDGEMENT}

The authors are thankful to University of Sargodha for providing the services to carried out this review.

\section{REFERENCES}

Akhter, M. J., Abbas, R. N., Waqas, M. A., Noor, M. A., Arshad, M. A., Mahboob, W., Nadeem, F., Azam, M., \& Gull, U. (2017). Adjuvant improves the efficacy of herbicide for weed management in maize sown under altered sowing methods. Journal of Experimental Biology and Agricultural Sciences, 5(1), 2230. http://dx.doi.org/10.18006/2017.5(1).022. 030

Alkari, S., \& Chaturvedi, A. (2014). Phytochemical basis of anti-inflammatory and ant-microbial activity of Achyranthes aspera. Biology, 8(23), 231-249. Retrieved from https://scholar.google.com/scholar?hl= id\&as_sdt $=0 \% 2 \mathrm{C} 5 \& \mathrm{q}=$ Phytochemical + basis + of+anti-inflammatory+and+ant-microbial+ac tivity+of+Achyranthes+aspera.\&btnG=.

Asif, M., Aziz, A., Nadeem, M. A., Safdar, M. E., Ali, A., Akhtar, N., Raza, A., Adnan, M., \& Hanif, M. S. (2020). Assessing the agronomic consequences of delayed removal of parthenium from forage sorghum (Sorghum bicolor). International Journal of Agriculture and Biology, 24(4), 737742. Retrieved from https://www.cabdirect. org/cabdirect/abstract/20203515032

Aziz, A., Asif, M., Munawar, A., Majeed, M. Z., Nadeem, M. A., Akhtar, N., Ashraf, M., Javaid, M. M., Adnan, M., Bhatti, M. A., \& Khan, B. A. (2021). Exploring the herbicidal potential of some weed species by using two distinct extraction methods. Agricultural and Biological Research, 37(1), 88-92. Retrieved from https://www.researchgate.net/ publication/348620899_Exploring_the_herbic idal_potential_of_some_weed_species_by_us ing_two_distinct_extraction_methods

Banerjee, N., \& Pandey, A. K. (2015). Reduction in growth and biological pigments present in 
Parthenium hysterophorus by the allelopathic leaf extract of Alstonia scholaris. International Journal of Recent Research in Life Sciences, 2(3), 62-67. Retrieved from https://www. paperpublications.org/issue/IJRRLS/Issue-3July-2015-September-2015

Bekeko, Z. (2013). Effect of urea and common salt $(\mathrm{NaCl})$ treated glyphosate on parthenium weed (Parthenium hysterophorus L.) at Western Hararghe zone, Ethiopia. African Journal of Agricultural Research, 8(23), 3036-3041. Retrieved from https://www. researchgate.net/publication/273838233_Afri can_Journal_of_Agricultural_Research_Effec t_of_urea_and_common_salt_NaCl_treated_g lyphosate_on_parthenium_weed_Parthenium _hysterophorus_L_at_Western_Hararghe_zon e_Ethiopia

Belgeri, A., Bajwa, A. A., Shabbir, A., Navie, S., Vivian-Smith, G., \& Adkins, S. (2020). Managing an invasive weed species, Parthenium hysterophorus, with suppressive plant species in Australian Grasslands. Plants, 9(11), 1587. https://doi.org/10.3390/plants911 1587

Cheema, Z. A., Khaliq, A., \& Hussain, R. I. A. Z. (2003). Reducing herbicide rate in combination with allelopathic sorgaab for weed control in cotton. International Journal of Agriculture and Biology, 5(1), 4-6. Retrieved from https://www.researchgate.net/ publication/266466877_Reducing_Herbicide_ Rate_in_Combination_with_Allelopathic_Sor gaab_for_Weed_Control_in_Cotton

Cheema, Z. A., Khichi, A. H., \& Khaliq, A. (2005). Feasibility of reducing herbicide dose in combination with sorgaab for weed control in transplanted fine rice (Oryza sativa L.). International Journal of Agriculture and Biology, 7(6), 892-894. Retrieved from https://www.researchgate.net/publication/238 102896_Feasibility_of_Reducing_Herbicide_ Dose_in_Combination_with_Sorgaab_for_W eed_Control_in_Transplanted_Fine_Rice_Or yza_sativa_L

Gnanavel, I. (2013). Parthenium hysterophorus L.: a major threat to natural and agroecosystems in India. Science International, 1 (5), 124-131. http://dx.doi.org/10.5567/sciintl. 2013.124.131
Government of Pakistan. (2019). Economic survey of Pakistan 2018-19. Economic Adviser's Wing, Finance Division Government of Pakistan, Islamabad. Retrieved from http://www.finance.gov.pk/survey_1819.html

Gupta, S., \& Narayan, R. (2010). Effects of applied leaf biomass of Parthenium hysterophorus, Cassia obtusifolia and Achyranthes aspera on seed germination and seedling growth of wheat and pea. Allelopathy Journal, 26(2), 59-70. Retrieved from https://www.researchgate.net/publication/249 009731_Effects_of_applied_leaf_biomass_of _Parthenium_hysterophorus_Cassia_obtusifol ia_and_Achyranthes_aspera_on_seed_germin ation_and_seedling_growth_of_wheat_and_p ea

Hazen, J. L. (2000). Adjuvants-terminology, classification, and chemistry. Weed Technology, 14(4), 773-784. https://doi.org/ 10.1614/0890-037X(2000)014[0773:ATCAC ]2.0.CO;2

Hess, F. D., \& Foy, C. L. (2000). Interaction of surfactants with plant cuticles. Weed Technology, 14(4), 807-813. https://doi.org/ 10.1614/0890-037X(2000)014[0807:IOSWP $\mathrm{C}] 2.0 . \mathrm{CO} ; 2$

Hussain, M., Adnan, M., Asif, M., Aziz, A., Ali, A., Khan, M. A. B., Hayyat, M. S., Iqbal, T., Bilal, H. M., Rahman, H. A. U., Toor, M. D., \& Ahmad, R. (2020). Management of weeds by using crop competition in mustard (Brassica juncea L.). International Journal of Biosciences, 17(6), 62-69. Retrieved from https://innspub.net/ijb/management-weedsusing-crop-competition-mustard-brassicajuncea-l/

Javaid, M. M., \& Tanveer, A. (2013). Optimization of application efficacy for POST herbicides with adjuvants on threecornered jack (Emex australis Steinheil) in wheat. Weed Technology, 27(3), 437-444. https://doi.org/10.1614/WT-D-11-00130.1

Javaid, M. M., Tanveer, A., Ahmad, R., Yaseen, M., \& Khaliq, A. (2012). Optimizing activity of herbicides at reduced rate on Emex spinosa Campd. with adjuvants. Planta Daninha, 30(2), 425-435. https://doi.org/10.1590/S01 00-83582012000200023 
Khan, H., Marwat, K. B., Hassan, G., \& Khan, M. A. (2012). Chemical control of Parthenium hysterophorus $\mathrm{L}$. at different growth stages in non-cropped area. Pakistan Journal of Botany, 44(5), 1721-1726. Retrieved from http://www. pakbs.org/pjbot/PDFs/44(5)/35.pdf

Khan, H., Marwat, K. B., Khan, M. A., \& Hashim, S. (2014). Herbicidal control of parthenium weed in maize. Pakistan Journal of Botany, 46(2), 497-504. Retrieved from https://www. pakbs.org/pjbot/PDFs/46(2)/13.pdf

Leszczyński, P., Panczyk, M., Podgórski, M., Owczarek, K., Gałązkowski, R., Mikos, M., Charuta, A., Zacharuk, T., \& Gotlib, J. (2019). Determinants of occupational burnout among employees of the Emergency Medical Services in Poland. Annals of Agricultural and Environmental Medicine, 26(1), 114-119. https://doi.org/10.26444/aaem/94294

Marwat, K. B., Hashim, S., \& Ali, H. (2010). Weed management: a case study from North-West Pakistan. Pakistan Journal of Botany, 42, 341-353. Retrieved from http:// www.pakbs.org/pjbot/PDFs/42(SI)/PJB42(SI) 341.pdf

Matloob, A., Safdar, M. E., Abbas, T., Aslam, F., Khaliq, A., Tanveer, A., Rehman, A., \& Chadhar, A. R. (2019). Challenges and prospects for weed management in Pakistan: A review. Crop Protection, 134, 104724. https://doi.org/10.1016/j.cropro.2019. 01.030

Mayo, Z. A., \& Abbas, S. (2020). Impact of parthenium weed on the yield of wheat crop in Sheikhupura and Rawalpindi Districts of the Punjab, Pakistan. Pakistan Geographical Review, 75(2), 301-314. Retrieved from http://pu.edu.pk/images/journal/geography/pd f/11_V75_No2_2020.pdf

Mehdizadeh, M., Mehdizadeh, Z., \& Baghaeifar, Z. (2020). Efficacy evaluation of tribenuron methyl herbicide by using different adjuvants for common Lambsquarters (Chenopodium album L.) control. International Journal of Advanced Biological and Biomedical Research, 8(1), 1-8. https://doi.org/10.33945/ SAMI/IJABBR.2020.1.1

Mehmood, K., Asif, H. M., Bajwa, R., Shafique, S., \& Shafique, S. (2011). Phytotoxic potential of bark extracts of Acacia nilotica and Syzygium cumini against Parthenium hysterophorus. Pakistan Journal of Botany, 43(6), 3007-3012. Retrieved from http:// www.pakbs.org/pjbot/PDFs/43(6)/60.pdf

Nosratti, I., Sabeti, P., Chaghamirzaee, G., \& Heidari, H. (2017). Weed problems, challenges, and opportunities in Iran. Crop Protection, 134, 104371. https://doi.org/ 10.1016/j.cropro.2017.10.007

Porwal, M. K., \& Singh, M. M. (1993). Efficacy of herbicides for weed control in cauliflower (Brassica oleracea L.). Indian Journal of Weed Science, 25(1\&2), 55-60. Retrieved from https://www.indianjournals.com/ijor.asp $\mathrm{x}$ ?target $=$ ijor:ijws \& volume $=25 \&$ issue $=1$ and 2 \&article $=011$

Powles, S. B., \& Yu, Q. (2010). Evolution in action: plants resistant to herbicides. Annual Review of Plant Biology, 61, 317-347. Retrieved from https://pubmed.ncbi.nlm.nih. gov/20192743/

Pratt, C. F., Constantine, K. L., \& Murphy, S. T. (2017). Economic impacts of invasive alien species on African smallholder livelihoods. Global Food Security, 14, 31-37. https://doi. org/10.1016/j.gfs.2017.01.011

Rehman, A., Hassan, F. U., Qamar, R., Ali, M., Zamir, M. S., Iqbal, S., Shehzad, M., Masood, N., \& Javeed, H. M. R. (2017). Efficacy of herbicides in controlling Parthenium hysterophorus L. in spring maize (Zea mays L.). Quality Assurance and Safety of Crops \& Foods, 9(2), 213-220. https://doi.org/10.3920/ QAS2015.0750

Rehman, A., Qamar, R., Safdar, M. E., Atique-urRehman, Javeed, H. M. R., Maqbool, R., Farooq, N., Shahzad, M., Ali, M., \& Tarar, Z. H. (2020). Critical competition period of Parthenium hysterophorus L. in spring maize (Zea mays L.). Planta Daninha, 38, 1-9. https://doi.org/10.1590/s0100-835820203801 00085

Safdar, M. E., Tanveer, A., Khaliq, A., \& Riaz, M. A. (2015). Yield losses in maize (Zea mays) infested with parthenium weed (Parthenium hysterophorus L.). Crop Protection, 70, 7782. https://doi.org/10.1016/j.cropro.2015.01.0 10 
Safdar, M. E., Tanveer, A., Khaliq, A., \& Maqbool, R. (2016). Critical competition period of parthenium weed (Parthenium hysterophorus L.) in maize. Crop Protection, 80, 101-107. https://doi.org/10.1016/j.cropro. 2015.11.002

Safdar, M. E., Tanveer, A., Khaliq, A., Ali, H. H., \& Burgos, N. R. (2016). Exploring herbicidal potential of aqueous extracts of some herbaceous plants against Parthenium weed. Planta Daninha, 34(1), 109-116. https:// doi.org/10.1590/S0100-83582016340100011

Safdar, M. E., Tanveer, A., Khaliq, A., Naeem, M. S., \& Ahmad, S. (2013). Tree species as a potential source of bio-herbicides for controlling Parthenium hysterophorus L. Natural Product Research, 27(22), 2154 2156. https://doi.org/10.1080/14786419.2013. 790028

Saha, B., Devi, C., Khwairakpam, M., \& Kalamdhad, A. S. (2018). Vermicomposting and anaerobic digestion-viable alternative options for terrestrial weed management-A review. Biotechnology Reports, 17, 70-76. https://doi.org/10.1016/j.btre.2017.11.005

Santos, R., Pires, T. P., Mesquita, M. L. R., Correa, M. J. P., \& Silva, M. R. M. (2020). Weed interference in okra crop in the organic system during the dry season. Planta Daninha, 38, 1-10. https://doi.org/10.1590/s0100-835 82020380100014

Sharma, A., Kumar, V., Shahzad, B., Tanveer, M., Sidhu, G. P. S., Handa, N., Kohli, S. K., Yadav, P., Bali, A. S., Parihar, R. D., Dar, O. I., Singh, K., Jasrotia, S., Bakshi, P., Ramakrishnan, M., Kumar, S., Bhardwaj, R., \& Thukral, A. K. (2019). Worldwide pesticide usage and its impacts on ecosystem. $S N$ Applied Sciences, 1(11), 1-16. https:// doi.org/10.1007/s42452-019-1485-1

Shekhawat, K., Rathore, S. S., Dass, A., Das, T. K., Mahajan, G., \& Chauhan, B. S. (2017). Weed menace and management strategies for enhancing oilseed brassicas production in the Indian Sub-continent: A review. Crop Protection, 96, 245-257. https://doi.org/ 10.1016/j.cropro.2017.02.017

Singh, C. M., Singh, S. D., \& Kumar, S. (1993). Study on the weed management in okra
(Bhindi) is a kharif season vege. Indian Journal of Weed Science, 25(1\&2), 92-95. Retrieved from https://www.indianjournals. com/ijor.aspx?target=ijor:ijws \&volume $=25 \& \mathrm{i}$ ssue $=1$ and $2 \&$ article $=020$

Singh, M. P., \& Singh, K. P. (1994). Effect of crop weed competition on growth and yield of Kharif onion. Indian Journal of Weed Science, 26(3\&4), 18-21. Retrieved from https://www. indianjournals.com/ijor.aspx?target=ijor:ijws $\&$ volume $=26 \&$ issue $=3$ and $4 \&$ article $=004$

Singh, S., Yadav, A., Balyan, R. S., Malik, R. K., \& Singh, M. (2004). Control of ragweed parthenium (Parthenium hysterophorus) and associated weeds. Weed Technology, 18(3), 658-664. https://doi.org/10.1614/WT-03-128 R2

Srivastav, S., Singh, P., Mishra, G., Jha, K. K., \& Khosa, R. L. (2011). Achyranthes aspera-An important medicinal plant: A review. Journal of Natural Products and Plant Resources, 1(1), 1-14. Retrieved from https://www. researchgate.net/publication/216410155_Ach yranthus_aspere-An_important_medicinal_ plant_A_review

Tagour, R. M. H., El-Hamed, G. M. A., \& EL-Metwally, I. M. (2011). Improving herbicides efficacy of topik and traxos on wheat plants and associated weeds by adjuvants arkopal. Nature and Science, 9(11), 176-183. Retrieved from http://free-journal .umm.ac.id/detail-6564-title-improving-herbi cides-efficacy-of-topik-and-traxos-on-wheatplants-and-associated-weeds-by-adjuvants-ar kopal.html

Tanveer, A., Abbas, N., Safdar, M. E., \& Ikram, R. M. (2017). Alkyl ether sulfate improves efficacy of herbicides against common goosefoot and field bindweed in wheat. Planta Daninha, 35, 1-10. https://doi.org/10.1590 /s0100-83582017350100084

Tanveer, A., Safdar, M. E., Tariq, M. A., Yasin, M., \& Noorka, I. R. (2014). Allelopathic inhibition of germination and seedling vigor of some selected crops by Achyranthes aspera $\mathrm{L}$. Herbologia, 14(2), 35-46. Retrieved from https://www.researchgate.net/publication/281 281535_ALLELOPATHIC_INHIBITION_O F_GERMINATION_AND_SEEDLING_VIG OR_OF_SOME_SELECTED_CROPS_BY_ 


\section{ACHYRANTHES_ASPERA_L}

Yahia, E. M., García-Solís, P., \& Celis, M. E. M. (2019). Contribution of fruits and vegetables to human nutrition and health. In Postharvest Physiology and Biochemistry of Fruits and Vegetables (pp. 19-45). Elsevier. https://doi. org/10.1016/B978-0-12-813278-4.00002-6

Zareen, S., Khan, S., Ahmad, I., Haroon, M., Khan, I., \& Ullah, I. (2017). Effect of various weed infested periods on okra under agroclimatic conditions of DI Khan, Pakistan. Pakistan Journal of Weed Science Research, 23(1), 91-101. Retrieved from https://www. researchgate.net/publication/327744866_EFF ECT_OF_VARIOUS_WEED_INFESTED_P ERIODS_ON_OKRA_UNDER_AGRO-CLI MATIC_CONDITIONS_OF_DI_KHAN_PA KISTAN 